\title{
Chapter 11 \\ Creating a Breeding Ground for Compliance and Honest Reporting Under the Landing Obligation: Insights from Behavioural Science
}

\author{
Sarah B. M. Kraak and Paul J. B. Hart
}

\begin{abstract}
Fisheries regulations aim to maintain fishing mortality and fishing impacts within sustainable limits. Although sustainability is in the long-term interest of fishers, the regulations themselves are usually not in the short-term interest of the individual fisher because they restrict the fisher's economic activity. Therefore, as is the case with all regulations, the temptation exists for non-compliance and dishonest reporting. In the EU and elsewhere, top-down, complex regulations, often leading to unintended consequences, with complex and non-transparent governance-science interactions, may decrease the credibility and legitimacy of fisheries management among fishers. This, in turn, may decrease the motivation to comply and report honestly. The Landing Obligation may make things worse because following the regulation to the letter would often strongly and negatively impact the individual fishers' economic situation. Behavioural science suggests factors that may influence compliance and honesty. Compliance is not necessarily a function of the economic benefits and costs of rule violation: compliance may be more or less, depending on intrinsic motivations. An increased level of self-decision may lead to greater buy-in to sustainable fishing practices and voluntary compliance to catch limits and the Landing Obligation. All else being equal, people in small and self-selected groups are inherently more likely to behave "prosocially". In this chapter, some key recommendations based on behavioural science are given for changes in institutional settings that may increase voluntary compliance and sustainable fishing practices. However, transition to a system allowing for more freedom from top-down regulation, with more self-governance, may be difficult due to institutional and cultural barriers and therefore may take many years.
\end{abstract}

\footnotetext{
S. B. M. Kraak (ه)

Thünen Institute of Baltic Sea Fisheries, Rostock, Germany

e-mail: sarah.kraak@thuenen.de

P. J. B. Hart

Department of Neuroscience, Psychology and Behaviour, University of Leicester, Leicester, UK
} 
Keywords Behavioural economics - Being watched - Carrot or stick · Hidden cost of control · Honest reporting $\cdot$ Lack of trust $\cdot$ Loss aversion · Moral priming · Nonmonetary incentives $\cdot$ Self-decision $\cdot$ Self-selected groups $\cdot$ Voluntary compliance

\subsection{Introduction}

Prior to the Landing Obligation, the main instrument to control fishing pressure in the European Union (EU) has been the setting of total allowable landings quotas (which have been called Total Allowable Catches, TACs). This instrument has allowed for implementation error because landings quotas do not limit catches. Under landings quotas, unlimited over-quota catches are allowed as long as they are not landed; in other words, they must be discarded at sea. The implementation error occurs because, when over-quota fish are caught and discarded dead, the intended level of exploitation set by the quotas is overshot, sometimes by large and often unknown amounts (Kelleher 2005). Reasons for discarding may be:

1. Fish smaller than the minimum landing size (MLS) have been caught and are not allowed to be landed.

2. Fishers may discard lower-quality fish and utilise their landings quota to land better-quality and higher-priced fish (high-grading) - this practice is forbidden in the EU since 2002, but no offenders have been caught and sanctioned (Schou 2015).

3. In mixed fisheries, fishers may catch over-quota fish when they continue fishing for other species whose quota is not yet exhausted - these fish, which may be (unavoidable, incidental) bycatch species or part of the targeted assemblage, must be discarded at sea (see BBC 2007; Borges and Penas-Lado, this volume).

The Landing Obligation, with total allowable catch quotas (limiting actual catches rather than only landings), attempts to make an end to the implementation error caused by the landings quota system. However, it is expected that the EU will experience problems in fully implementing the Landing Obligation if the incentives for discarding continue to exist. For example, although the MLS is abolished under the Landing Obligation, fish smaller than a minimum conservation reference size (MCRS) are not permitted to be sold for human consumption and thus have a lower value. Therefore, incentives for illegally discarding fish below MCRS and highgrading may continue to exist. In addition, in several fishing areas, the problem of "choke species" may arise in mixed fisheries or fisheries with unavoidable bycatch (Prellezo et al. 2016; Fitzpatrick et al., this volume). In such cases the fishery for important commercial species is "choked", i.e. must be closed, before its quota is fished up, because the quota for another species caught in the same fishery is already exhausted. This situation creates incentives to illegally discard over-quota catches of the choke species and continue fishing. 
Thus, the EU's Common Fisheries Policy (CFP) can only be fully implemented if the Landing Obligation is fully complied with and catch limits are not exceeded. However, it is not yet clear how to achieve this: it is not specified how the catch limits and Landing Obligation will be enforced and how catches will be verified. The regulation leaves the documentation and compliance monitoring to the Member States (EU 2013, Article 15.13):

For the purpose of monitoring compliance with the Landing Obligation, Member States shall ensure detailed and accurate documentation of all fishing trips and adequate capacity and means, such as observers, closed-circuit television (CCTV) and others. In doing so, Member States shall respect the principle of efficiency and proportionality.

Assuming that catches cannot be completely observed, counted, documented and verified, the regulation leaves room for implementation error, in two ways:

1. Directly: Fishers may still catch (and discard) in excess of the quotas.

2. Indirectly: Removals will be known to stock assessment scientists with a certain degree of uncertainty. This will lead to imprecise estimates, advice and management measures, for example, too low or too high a TAC. Prior to the Landing Obligation, this has been commonly the case. Scientists have attempted to estimate the removals (including discards) through sampling trips with observers on board. Problems of reliability and representativeness of the samples may, however, increase under the Landing Obligation, because fishers may fear that when scientists are aware of law violations this information will be passed on to the enforcement authorities. To mitigate this problem, data collection for science (i.e. stock assessment) should be kept strictly separated from data collection for enforcement purposes (Mangi et al. 2013). For example, it has been found that Norwegian fishers report bycatch of rare species in scientific programmes, but not in their logbooks, although such reporting is obligatory (J. Vølstad, personal communication).

The implementation error can only be avoided if full trustworthiness or full proof of the catches can be ensured. Full documentation (i.e. proof) of the catch can be achieved by Remote Electronic Monitoring (REM or EM) systems such as camera and sensor systems (for more details, see James et al., this volume), leading to a fully documented fishery (FDF), but these systems are costly, and fishers are often averse to being watched. Some EU Member States also expressed a dismissive attitude towards the use of cameras for monitoring purposes, presumably fearing to turn an anti-FDF-minded sector against their ministry.

Persuading fishers to follow regulations has been one of the toughest problems to be solved in fisheries. In an effort to deal with the difficulty, co-management has been introduced and become more common than it once was (Jentoft 1998; Wilson et al. 2003; Jacobsen et al. 2012). Co-management allows fishers to contribute to the formulation of regulations and gives them a say in how they are applied. Studies in behavioural economics have shown that a feeling of ownership encourages participants to value more highly something that they have put effort into achieving (Norton et al. 2012). Unfortunately, at the level of the EU, the co-management 
approach is not yet widespread, and the implementation of the Landing Obligation is a top-down regulation that requires fishers to follow a rule that can result in economic outcomes for the individual that could lead to resistance.

\subsection{The Commercial Pressures Influencing Fisher Decisions}

If management agencies want their rules to be followed, then it is essential that those rules are devised with regard to the commercial pressures on fishers. Rules are more likely to fail if they make it difficult for a fisher to make ends meet financially. This is why the TAC approach, when applied to a mixed fishery, often failed. If her/his trawl emerges from the depths with a catch of a species for which she/he has no quota, then a fisher can be faced with a dilemma. Under the old TAC system, if the fish have market value as is shown in Fig. 11.1, this situation creates the temptation to keep the fish and sell them illegally, and this temptation would be particularly acute if the fisher's economic situation is poor (Booker 2007; BBC 2007). Recognising that under the old TAC system fishers could be regularly faced with this dilemma does not prove that many fishers submitted to the temptation, but gathering evidence for illegal sales of non-quota fish is difficult by its nature although the problem of illegal, unreported and unregulated (IUU) fishing has been extensively examined (Le Gallic and Cox 2006; Sumaila et al. 2006). In certain parts of the world, there is no doubt that illegal fish are landed and sold, and there is also evidence that this happens within EU waters (Couper et al. 2015). Under the new Landing Obligation, the fisher has to stop fishing, even if she/he has quota left for other species, and this will also have economic consequences. For this reason, both management regimes are vulnerable to abuse if the fisher's economic circumstances are poor. It may be necessary in this situation to find alternatives to top-down regulations, which would focus on giving fishers greater power to devise regulations.

\subsection{Behavioural Economics: A Discipline Providing Guidance for Addressing the Problem}

In the rest of this chapter, we aim to give some guidance on how fishers can be encouraged to stay within the catch limits and to report catches accurately by using insights from the behavioural sciences, specifically the discipline of behavioural economics. Behavioural economics studies the effects and consequences of psychological, social, cognitive and emotional factors on the economic decisions of individuals and institutions, challenging the assumption of human rationality that prevails in classical economic theory (Dhami 2016). Behavioural economics is an empirical science based on experimental work: the behaviour and choices of human 


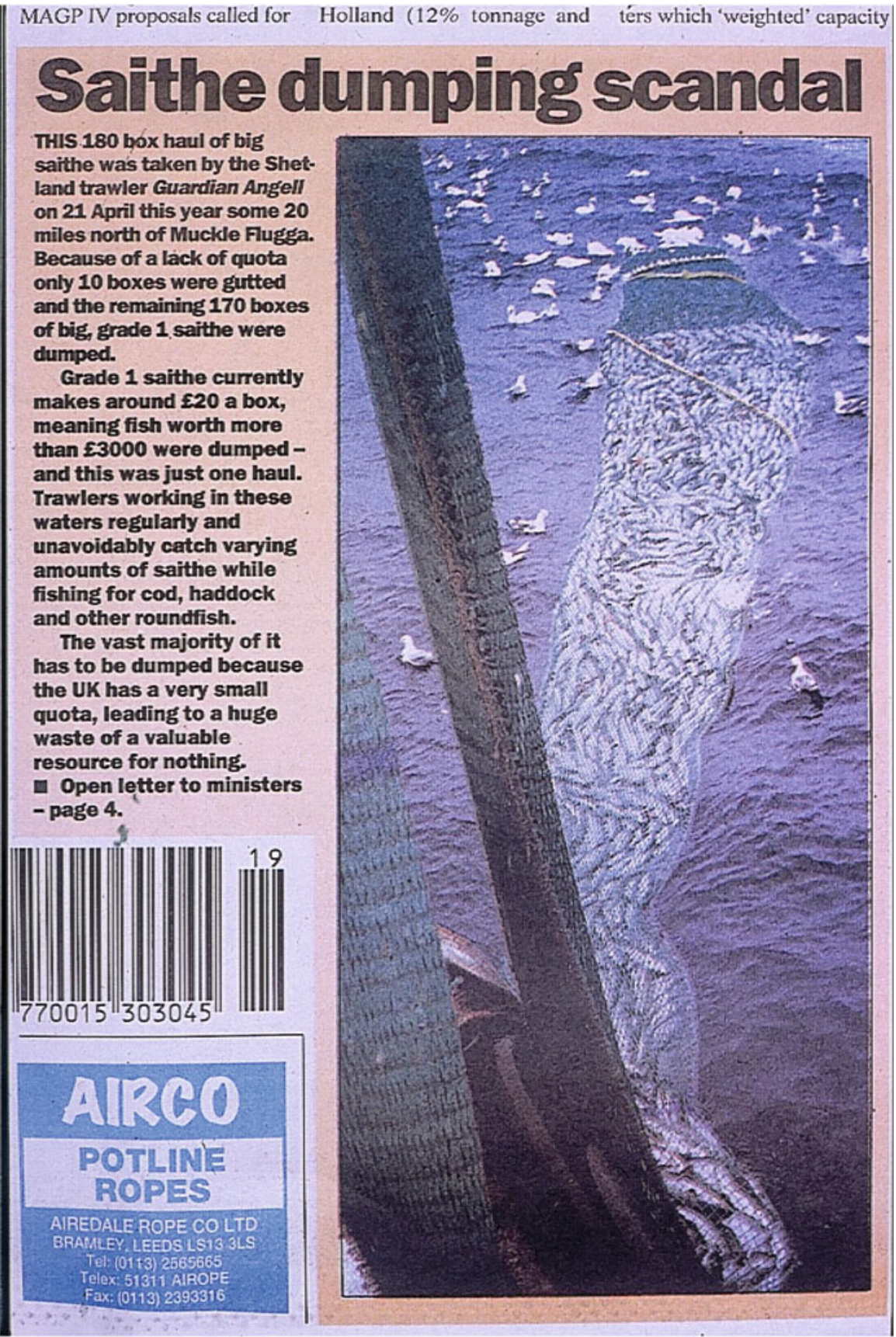

Fig. 11.1 An example of how, under the old TAC system, fishers could be tempted to land illegally dead fish which could not legally be landed. (From Fishing News, UK) 
subjects are observed under controlled experimental conditions. The value of behavioural economics in the creation of policy has been given its highest profile by Thaler and Sunstein (2009). They used the terms "nudge" and "nudging" to characterise measures they proposed to encourage people to make decisions that comply with policy or achieve long-term goals. They made suggestions, for example, for how to design procedures to encourage people to submit their tax returns on time or to save more for retirement. The British Government in 2010 was so impressed by the approach that it set up the Behavioural Insights Team which is tasked to "...use insights from behavioural science to encourage people to make better choices for themselves and society" (Behavioural Insights Team 2018). In 2015, Barack Obama, then US president, established the Social and Behavioral Sciences Team charged with a similar task (Congdon and Shankar 2018). Much of what we offer in this chapter is in the same vein.

To find ways of improving the chances of fishers following the rules, we discuss how the following selection of ideas from behavioural economics could contribute to better compliance to the Landing Obligation:

- Determinants of honesty and respect for the law

- Crowding out of voluntary compliance

- The effects of being watched

- Loss aversion

\subsubsection{Determinants of Honesty and Respect for the Law}

In most countries, the standard approach to obtaining fisher compliance is to deter rule violations through investments in enforcement activities, including at-sea patrols, dockside monitoring and observer programmes (see also James et al., this volume). This approach is built on the assumption that the occurrence of fishery offences is solely a function of the perceived benefits and costs of an offence, such as the gains derived from rule violation, the likelihood of detection and the severity of the penalties (Becker 1974; Hart 1997). However, modern criminology (e.g. Tyler 2006) and behavioural economics (Mazar et al. 2008) recognise that many people comply with rules because they believe it is the right thing to do. In this context, tax compliance is much higher than deterrence models would predict (Frey and Torgler 2007). Individuals are also much influenced by the majority view of the group they are part of (e.g. Aronson and Aronson 2012). When we witness unethical behaviour, our own morality erodes (Ariely 2012). Cheating can be socially contagious (Gino et al. 2009; Mann et al. 2014): as long as we see members of our own social groups behaving in ways that are dishonest, it is likely that we too will recalibrate our internal moral compass and adopt their behaviour as a model for our own. Tax compliance, for example, varies widely across European countries, and a high correlation has been found between perceived tax evasion and tax morale (Frey and Torgler 2007). Similarly, experimentally measured, individual intrinsic honesty 
is stronger in the subject pools of countries with lower levels of corruption, tax evasion and fraudulent politics than in those of countries where the latter are higher (Hermann et al. 2008; Gächter and Schulz 2016). Individuals may even feel pride about breaking the rules. A study among Danish fishers (Nielsen and Mathiesen 2003) reported that they "feel they are taken hostage by an illegitimate management system, and thus feel it is morally correct not to comply". Within a fishery where crews know each other through the use of a common port, it may be possible to enhance compliance by fostering pride (see Panagopoulos 2010; Harth et al. 2013) about sustainable fishing practices by publishing stories in the fishing press about fishers that have complied.

In laboratory experiments, Mazar et al. (2008) found that (1) the amount of dishonesty is largely insensitive to either the expected external benefits or the costs associated with the deceptive acts; (2) causing people to become more aware of their internal standards for honesty by moral priming decreases their tendency for deception; and (3) increasing the "degrees of freedom" that people have to interpret their actions increases their tendency for deception. For instance, Mazar et al. (2008) found that nonmonetary crime targets (i.e. property rather than money) can increase economically incentivised dishonesty in a laboratory setting. Similar laboratory studies by Mead et al. (2009) found that mental tiredness also increases cheating. These two studies suggest that violation of fishing regulations could at least in part be exacerbated by a lack of moral reminders, the opportunity to "steal" a nonmonetary asset (i.e. fish) and the mental tiredness of fishers. A further complication in a fishery is that the fisher and his crew are often on their own at sea, so that social pressures regarding compliance are distanced from the act of disobedience. Mazar et al. (2008) suggest that understanding dishonesty has important implications for designing effective methods to curb it. The costs of obtaining a particular level of fisheries compliance through enforcement could potentially be reduced through increased investments in activities that improve voluntary compliance.

Studies (e.g. Mazar et al. 2008) have indicated that honesty can be enhanced by moral reminders, such as simply asking people to sign a statement in which they declare their commitment to honesty before taking part in a task rather than after (e.g. signing the honesty statement on the income tax declaration form at the top rather than at the bottom). In fisheries this finding could be applied by making fishers sign the logbook just before logging the information (Kraak et al. 2015). The e-log system could have a confirmation screen which requires the operator to acknowledge that they are filling the form out accurately before the electronic system can receive data input.

A recent experiment showed how priming can affect honest reporting by fishers (Drupp et al. 2016). Using a coin-tossing task, the authors tested whether truthtelling of German fishers, who are known to dislike their EU regulator, is affected by various treatments. Fishers misreported coin tosses to their economic advantage more strongly in a treatment where they were faced with the EU logo. Fishers were more honest in an additional treatment where the source of research funding, namely the EU, was revealed. These apparently contradictory findings suggest that lying is increased towards a disliked regulator, but perhaps decreased when it 
is made clear from whom the money is "stolen". The implication is that regulators can affect truth-telling behaviour by the nature and communication of their policies.

\subsubsection{Crowding Out of Voluntary Compliance}

Compliance with the rules is more likely when fishers, whose behaviour is to be regulated, buy-in to those rules. Fisheries management is in many cases a top-down bureaucratic process with centralised control (Daw and Gray 2005). The regulations are viewed by the fishers as opposing rather than supporting their interests, and this manifests itself as a reduced compliance to "the letter" as well as "the spirit" of the regulations (Kuperan and Sutinen 1998; Hatcher et al. 2000; Nielsen 2003; Nielsen and Mathiesen 2003; Kraak 2011). Evidence suggests that the willingness to obey regulations voluntarily depends on whether one is controlled or not (reviewed in Bowles 2008; Richter and van Soest 2012). Counterintuitively, the control imposed by an outside institution undermines - "crowds out" - any intrinsic motivations an individual may have to comply voluntarily. As a result, there is a hidden cost of control, as pointed out by Falk and Kosfeld (2006). The implication is that control can "crowd out" intrinsic motivations, calling for even stronger control, leading to a vicious cycle of mistrust and strong controls. Behavioural economics has established that regulations that are chosen by the individuals (e.g. via voting) are obeyed more, as they are perceived to be more legitimate (Vyrastekova and van Soest 2003). It is apparent from the work of Ostrom that self-imposed rules, self-imposed monitoring and self-imposed sanctions work better (Ostrom 2009). One of the reasons is that control by an outside institution signals mistrust, which directly affects motivational factors, such as cooperation, reciprocity or being a good citizen.

Indeed, fisheries systems can be characterised by mutual mistrust, between regulators and fishers, between scientists and fishers and among fishers themselves. Fishers have lost respect for the rules and regulations because many of them do not seem to make sense (including the Landing Obligation), seem too complex, seem contradictory or seem to provide perverse incentives (Jentoft 1998; Jacobsen et al. 2012). At the same time, fishers are usually not expected to voluntarily take action to fish more sustainably as this would be perceived to reduce rather than maximise catches. Often the institutional set-up is such that fishers are perceived as the adversaries of the management establishment. The key challenge for European fisheries is how one can "crowd in" desirable behaviour by establishing trusting relationships. The problem seems to be how to make such a transition from the current situation - rebuilding of mutual trust cannot be done simply on a short time scale.

Large group size and anonymity may be among the causes of the apparent lack of trust. Social capital, trust and intrinsic motivation to cooperate tend to be higher in small groups of people who regularly interact with each other in non-anonymous ways (Henrich 2004). For example, in mixed fisheries, where vulnerable bycatch species effectively become the choke species, it is advantageous to join in groups 
and share the individual small bycatch quota (Holland and Jannot 2012; O'Keefe and DeCelles 2013). In the case of the US West Coast (Holland and Jannot 2012), groups of fishers pooling their quotas can set their own rules, not necessarily encoded in law. These people were not necessarily connected in communities before; they came together because they have a common problem that can best be solved by collective action. Also in Europe there are examples of fishers voluntarily pooling their quotas: in a Danish village, boat owners and fishers have established a cooperative company where they have bought quotas jointly, with the aim of securing the community of its present and future catch rights (Schou 2011). In that way, the cooperative company replaces the Danish state as provider of fishing rights. In Toyama Bay, Japan, some of the inshore fishers pool their catches and their costs, others do not. Experiments demonstrated that the fishers who pooled costs and catches were more likely to show cooperative behaviours in laboratory experiments than were the fishers who did not share fishery costs and catches (Carpenter and Seki 2011). Several economic experiments have established that group choice is a key point to facilitate cooperative behaviour. If individuals can self-select into groups, there is a larger tendency to act in the group's interest and also to coordinate on a common cooperative strategy (Brekke et al. 2011; Gürerk et al. 2006).

Operating in groups/cooperatives may be more or less attractive to fishers: a perceived advantage may be the sharing of risk but a perceived disadvantage may be that the individual surrenders her/his own decision-making for the sake of democratic group decision-making. Kraak et al. (2015) proposed that fisheries management could set up a structure in which several levels of organisation are offered to which individual fishers can opt in (e.g. voluntary pooling of quotas); each level has its benefits and costs, but because the individuals can choose themselves, there would be greater acceptance of the disadvantages of the chosen setting. There are significant costs of managing a group/cooperative that need to be covered. To the extent that social behaviour of fishers in small groups decreases the negative externalities to society, e.g. those caused by non-compliance, policies can be designed that effectively subsidise those groups/cooperatives. This can be done in the form of setting aside a portion of the Member State's quota for such social initiatives or else by financial instruments.

Fishers often distrust managers and scientists and vice versa. The co-management movement which has been taking hold in various locations, particularly for smallscale fisheries, is designed to address this lack of trust between fishers, scientists and policy-makers (Wilson et al. 2003; and see papers in Chuenpagdee 2011). To varying degrees, co-management arrangements involve fishers in gathering data, translating their local ecological knowledge to a form which can be incorporated into stock assessments, determining policy and setting regulations. These systems give the fisher a sense of belonging and break down the barriers between the fisher and the regulator. In order to build mutual trust between fishers and scientists, industryscience collaborative projects could be established (e.g. Mangi et al. 2018), for example, in which fishers could try new practices and scientists explore the consequences. In the USA as well as in Europe, various scientist-facilitated initiatives are arising where scientists process and display information that fishers provide to share 
among themselves, for example, on CPUE hotspots or bycatch rates of species that need to be avoided so that fishers can catch their quotas at a lower impact to the ecosystem (e.g. O'Keefe and DeCelles 2013; Hetherington 2014; Eliasen and Bichel 2016). In collaboration with scientists, the fishing industry can create fishery management plans which comply with management policies. In the Netherlands and the UK, fishing organisations have started to hire scientists that were previously employed by the government to help them check assessments and advice and develop plans.

There are also initiatives to improve the knowledge of fish biology, fishery science and policy-making in fishers, which may further contribute to a more trusting relationship between fishers on the one hand side and regulators and scientists on the other. For example, in the UK, Fishing into the Future (2018) is run by fishers and, among other things, is running courses to broaden the education of fishers. A similar project has run in the Netherlands (Wageningen University and Research 2018), where fishers set up "knowledge groups" around themes and then interacted with fisheries scientists to access scientific knowledge. In the USA, the Marine Resource Education Programme, run by the Gulf of Maine Research Institute in Boston, similarly runs courses in fishery science for fishers.

The "crowding out" hypothesis does not only state that control may undermine intrinsic motivations to comply, but also that monetary incentives may undermine such motivations. In experiments and in the field it has been found that sometimes financial incentives induced more self-interested behaviour, even after they were withdrawn (Bowles 2008). For example, in a study by Cardenas et al. (2000), experiments were run with people in rural Colombia who are confronted with a common pool problem in their daily life. In the experiment subjects were asked to decide how much timber to extract from a forest. The scenario presented was that harvesting had an adverse effect on water quality (as is actually the case in the study region), posing a cost to everyone in the group. The game was played first without any regulations in place, while at a later stage, an extraction norm was introduced that was enforced by a mild probabilistic fine. Cardenas et al. (2000) found that subjects reduced their extraction level immediately after the regulation was introduced but started extracting more aggressively after realising that consequences were rather mild. Strikingly, in the last rounds, extraction levels were higher with the regulation than without. As a result, payoffs were significantly lower when individuals were confronted with a formal rule than in its absence; the weak official rule interacted with the internal norms of the subjects and destroyed their intrinsic motivation to cooperate (Cardenas et al. 2000). Richter and van Soest (2012) reviewed similar experiments, such as the one where imposing a fine on parents arriving late to collect their children at day care increased the number of late-coming parents or the one where small honoraria for seminar speakers may increase the probability of declining the invitation. More generally, in experiments investigating the psychological consequences of money, subjects exposed to the concept of money subsequently showed a more self-reliant but also more self-centred approach to problem-solving than subjects exposed to neutral concepts (Vohs et al. 2006). These results suggest that the application of nonmonetary incentives in fisheries 
management should be explored, along with other factors enhancing intrinsic compliance motivation such as moral reminders, non-anonymity, small group size and face-to-face communication. Nevertheless, Bowles (2008) and Richter and van Soest (2012) warn that the loss of social capital may, to a large extent, be irreversible and that from the reviewed experiments, it cannot simply be concluded that regulations or sanctions should be abolished.

\subsubsection{The Effects of Being Watched}

Technologies have recently emerged for monitoring fishers, such as AIS (automatic identification system), VMS (vessel monitoring system) and drones (Toonen and Bush 2018), but also Electronic Monitoring with cameras on board as a tool for a fully documented fishery (FDF) (James et al., this volume). As mentioned above, some EU Member States expressed a dismissive attitude towards the use of cameras for the purpose of monitoring. The aversion to being watched is in agreement with the notion that too much monitoring may have the result that individuals feel they are not trusted and as a consequence become less trustworthy (Ostrom 1998). In contrast, it has been well documented that people will be more likely to behave "prosocially" (e.g. cooperate, comply, be honest) when being watched in non-anonymous situations (reviewed in Kraak 2011). This occurs because it opens possibilities of direct and indirect reciprocity as well as reputation building - the psychological mechanism may be that good behaviour instils pride or, conversely, it can be driven by the fear of social exclusion when damaging one's reputation (Ouwerkerk et al. 2005). Recent investigations have shown that subtle cues of being watched, such as two stylised eye-like shapes on a computer screen suffice to change human behaviour and reduce selfishness; these eye-shaped cues seem to elicit unconscious, biologically hardwired reactions (Milinski and Rockenbach 2007). Perhaps a way to exploit this human propensity, without the disadvantage of eroding trust due to too much monitoring, is to display a picture of "watching eyes" on the e-logbook screen (Kraak et al. 2015) or anywhere on the vessel.

To persuade fishers to deploy a fully documented fishery, its advantages could be emphasised more clearly to the fishers. Full documentation of the fish supply chain (from net to plate) could bring strong market incentives through information on sustainability of the species, traceability and documentation on how the fish has been caught and treated on board (Mangi et al. 2013). The concepts of traceability and transparency could also be used in more innovative ways. As mentioned above, humans are not only subject to an aversion of being watched, but people may also like being watched when they are proud of what they are doing within the context of a peer group. In the UK, the Moshi Moshi sushi restaurant chain labels fish dishes with Quick Response (QR) codes printed with squid ink on rice paper so that customers can see where the MSC-certified fish comes from (SeafoodSource 2018). In Canada an organisation called This Fish (This Fish 2018) is setting up a system whereby consumers can use QR codes to identify the fisher who caught the 
product that is just about to be purchased or eaten. In other markets (meat products), this form of information promotes trust from the consumer, but in the fisheries case, it may also promote compliance from the fishers by instilling in them a greater sense of ownership of the final product (Kraak et al. 2015).

Further research on the "being-watched" effect should be done with experiments that are relevant to the specific settings encountered in fisheries management.

\subsubsection{Loss Aversion and the Use of "Carrot" or "Stick" Approaches}

In some Member States, pilot projects offered extra quota to participating fishers in return for providing full documentation of their catches for monitoring purposes (fully documented fishery) (van Helmond et al. 2015; Needle et al. 2015; Mortensen et al. 2017). This could be extended in, for example, a tiered approach stipulating that the fishers opting for a fully documented fishery would be subjected to less prescriptive rules and hence have more perceived freedom and flexibility in running their business, while the fishers opting for less stringent monitoring would have to bear the burden of more uncertain catch documentation and be subjected to more restrictive rules and/or a larger reduction of their quotas (Prellezo et al. 2016). Such approaches are framed as a "carrot", where a reward is given for the desired behaviour. The approach, however, can also be framed as a "stick", where a penalty is given when the desired behaviour is not chosen (e.g. where quota would be deducted or restricting rules would be imposed if fishers do not take up the fully documented fishery option). The response to "carrots" versus "sticks" should be carefully considered (Kubanek et al. 2015). Human beings are known to be subject to loss aversion (Tversky and Kahneman 1974, 1991): it is thought that the pain of losing is psychologically about twice as powerful as the pleasure of gaining; "losses loom larger than gains" (Kahneman and Tversky 1979). According to the expectation of loss aversion, the "stick" may be the stronger motivator than the "carrot" (Imas et al. 2017). The recent EU pilot projects with catch quotas and a fully documented fishery have used the "carrot" (van Helmond et al. 2015; Needle et al. 2015; Mortensen et al. 2017). On the other hand, the EU cod plan (EU 2008) used the "stick" of effort reductions to motivate (groups of) fishers to take up cod avoidance measures, but this was not well received by the fishing sector (Kraak et al. 2013). Since 2018, Germany offers a mobile app to small-scale fishers in the Western Baltic with which they can document where they are fishing. Only when they can prove that they are fishing in water less than $20 \mathrm{~m}$ deep are the small-scale fishers allowed to fish in a seasonally closed area (BLE 2018). The provision is formally phrased as a "carrot" (when using the app, they gain the right to fish in the otherwise closed area during the cod spawning season). However, some fishers perceive it as a "stick" (losing the opportunity to fish in the area unless using the 
app) because the area closure had never been sufficiently well enforced in previous years.

Kraak et al. (2016) suggested that a "stick" approach may induce a negative emotional response to management regulations, which may in turn induce reduced compliance (see also Imas et al. 2017). Accordingly, a potential trade-off might exist between the higher management effectiveness of a "stick" approach and reduced compliance with regulation. In order to find out what kind of framing would lead to highest uptake of the desired behaviour (e.g. a fully documented fishery and compliance), directed research on the response of fishers to "sticks" and "carrots" is needed.

\subsection{Conclusions}

In conclusion, much of the past implementation error has been caused because the complex top-down control and lack of trust have undermined potential intrinsic motivation to fish sustainably. Compliance is not necessarily a function of the economic benefits and costs of rule violation: compliance may be more or less, depending on intrinsic motivations and the economic circumstances of the fisher. An increased level of self-decision may lead to more buy-in to sustainable fishing practices and voluntary compliance to catch limits and the Landing Obligation. All else being equal, people in small and self-selected groups are inherently more likely to behave in a "prosocial" manner (Ostrom 1990, 2001). However, transition to a system allowing for more freedom from top-down regulation, with more selfgovernance and self-regulation, may be difficult. Some key recommendations are given below, several of which can be characterised as "nudges" as defined by Thaler and Sunstein (2009):

- Increase regulators' trust of fishers through a fully documented fishery.

- Increase fishers' trust of regulators by designing simpler legislation, with non-contradictory rules, which do not lead to perverse incentives.

- Increase fishers' trust of scientists and scientists' trust of fishers by setting up industry-science partnerships and collaborative research.

- Increase fishers' mutual trust and their intrinsic motivations to fish sustainably by facilitating and encouraging fishers to organise themselves in small groups with common interests.

- Allow for several levels of organisation to choose from, and allow for selfselection of group membership.

- Incentivise the organisation of fishers into groups through the provision of, for example, extra quota and relative freedom from top-down regulation or through financial instruments.

- Allow small groups of fishers to make their own decisions, where their own rules and sanctions do not necessarily have to be coded in law. 
- Incentivise uptake of a fully documented fishery, but carefully consider whether a "stick" or a "carrot" should be used.

- Allow groups of fishers to decide themselves on the methods of implementation of a fully documented fishery.

- Do not only rely on monetary incentives and monetary penalties; these may "crowd out" intrinsic motivations.

- For groups of fishers who know each other, publish examples of cooperative behaviour in the local press. Publishing the good behaviour of named fishers may be a nonmonetary incentive because it fosters pride of being a sustainable (good) fisher.

- Establish QR codes (Quick Response codes) that link a product to an individual fisher to foster a sense of being watched as well as ownership and pride in being a sustainable fisher.

- Use moral reminders in the e-log software, such as a requirement to sign a statement of accurate reporting at the start of their e-log session (instead of at the end), and pictures of watching eyes on the screen.

Acknowledgements The ideas brought forward in this chapter are largely based on the BehavFish workshop funded by the ICES Science Fund and the Fisheries Society of the British Isles (Kraak et al. 2015), and we therefore thank all participants of this workshop: Chris Anderson, Dorothy Dankel, Matteo Galizzi, Mark Gibson, Diogo Gonçalves, Katell Hamon, Ciaran Kelly, JeanJacques Maguire, Jeroen Nieboer, Ingrid van Putten, Andrew Reeson, Dave Reid, Andries Richter and Alessandro Tavoni.

\section{References}

Ariely, D. (2012). The (honest) truth about dishonesty. New York: Harper Collins.

Aronson, E., \& Aronson, J. (2012). The social animal, 11th edn. London: Macmillan.

BBC (2007). http://news.bbc.co.uk/1/hi/uk/7102241.stm. Accessed 12 June 2018.

Becker, G.S. (1974). Crime and punishment: an economic approach. Journal of Political Economy, 76(2), 169-217.

Behavioural Insights Team (2018). https://www.behaviouralinsights.co.uk/. Accessed 26 June 2018.

BLE (Bundesanstalt für Landwirtschaft und Ernährung) (2018). Bekanntmachung zur Fischerei auf Dorsch im Jahr 2018 unter der Ausnahmemöglichkeit innerhalb der Schonzeiten nach der Verordnung (EU) 2017/1970. Bundesanzeiger vom 8. Januar 2018.

Booker, C. (2007). Fishing quotas are an ecological catastrophe. https://www.telegraph.co.uk/news/ uknews/1570439/Fishing-quotas-are-an-ecological-catastrophe.html. Accessed 21 June 2018.

Borges, L., \& Penas-Lado, E. (this volume). Discards in the common fisheries policy: The evolution of the policy. In S.S. Uhlmann, C. Ulrich, S.J. Kennelly (Eds.), The European Landing Obligation - Reducing discards in complex multi-species and multi-jurisdictional fisheries. Cham: Springer.

Bowles, S. (2008). Policies designed for self-interested citizens may undermine "the moral sentiments": evidence from economic experiments. Science, 320(5883), 1605-1609.

Brekke, K.A., Hauge, K.E., Lind, J.T., Nyborg, K. (2011). Playing with the good guys. A public good game with endogenous group formation. Journal of Public Economics, 95(9), 1111-1118. 
Cardenas, J.C., Stranlund, J., Willis, C. (2000). Local environmental control and institutional crowding-out. World Development, 28, 1719-1733.

Carpenter, J.P., \& Seki, E. (2011). Do social preferences increase productivity? Field experimental evidence from fishermen in Toyama Bay. Economic Inquiry, 49(2), 612-630.

Chuenpagdee, R. (Ed.). (2011). World small-scale fisheries. Contemporary visions. Delft: Eburon.

Congdon, W.J., \& Shankar, M. (2018). The role of behavioural economics in evidence-based policymaking. The ANNALS of the American Academy of Political and Social Science, 678 (1), 81-92.

Couper, A., Smith, H.D., Ciceri, B. (2015). Fishers and plunderers. Theft, slavery and violence at sea. London: Pluto Press.

Daw, T., \& Gray, T. (2005). Fisheries science and sustainability in international policy: a study of failure in the European Union's Common Fisheries Policy. Marine Policy, 29(3), 189-197.

Dhami, S. (2016). The foundations of behavioral economic analysis. Oxford: Oxford University Press.

Drupp, M.A., Khadjavi, M., Quaas, M.F. (2016). Truth-telling and the regulator. Evidence from a field experiment with commercial fishermen (Kiel Working Paper 2063). https://www.ifw-kiel.de/ datenmigration/publikationen/document-store/truth-telling-and-the-regulator-evidence-from-a-fie ld-experiment-with-commercial-fishermen-7902/. Accessed 19 November 2018.

Eliasen, S.Q., \& Bichel, N. (2016). Fishers sharing real-time information about "bad" fishing locations. A tool for quota optimisation under a regime of landing obligations. Marine Policy, $64,16-23$.

European Union. (2008). Council Regulation (EC) No 1342/2008 of 18 December 2008 establishing a long-term plan for cod stocks and the fisheries exploiting those stocks and repealing Regulation (EC) No 423/2004. Official Journal of the European Union L, 348, 20-33.

European Union. (2013). Regulation (EU) No 1380/201308 of the European Parliament and of the Council of 11 December 2013 on the Common Fisheries Policy, amending Council Regulations (EC) No 1954/2003 and (EC) No 1224/2009 and repealing Council Regulations (EC) No 2371/ 2002 and (EC) No 639/2004 and Council Decision 2004/585/EC. Official Journal of the European Union. L, 354, 22-61.

Falk, A., \& Kosfeld, M. (2006). The hidden costs of control. American Economic Review, 96(5), $1611-1630$.

Fishing into the Future (2018). https://www.fishingintothefuture.co.uk/. Accessed 31 May 2018.

Fitzpatrick, M., Frangoudes, K., Fauconnet, L., Quetglas, A. (this volume). Fishing industry perspectives on the EU Landing Obligation. In S.S. Uhlmann, C. Ulrich, S.J. Kennelly (Eds.), The European Landing Obligation - Reducing discards in complex multi-species and multijurisdictional fisheries. Cham: Springer.

Frey, B.S., \& Torgler, B. (2007). Tax morale and conditional cooperation. Journal of Comparative Economics, 35(1), 136-159.

Gächter, S., \& Schulz, J.F. (2016). Intrinsic honesty and the prevalence of rule violations across societies. Nature, 531, 496-499.

Gino, F., Ayal, S., Ariely, D. (2009). Contagion and differentiation in unethical behavior: the effect of one bad apple on the barrel. Psychological Science, 20(3), 393-398.

Gürerk, Ö., Irlenbusch, B., Rockenbach, B. (2006). The competitive advantage of sanctioning institutions. Science, 312(5770), 108-111.

Hart, P.J.B. (1997). Controlling illegal fishing in closed areas: the case of mackerel off Norway. In: D.A. Hancock, D.C. Smith, A. Grant, et al. (Eds.), Developing and sustaining world fisheries resources: the state of science and management. 2nd world fisheries congress proceedings. Brisbane, Australia, pp. 411-414.

Harth, S.N., Leach, C.W., Kessler, T. (2013). Guilt, anger, and pride about in-group environmental behaviour: different emotions predict distinct intentions. Journal of Environmental Psychology, $34,18-26$.

Hatcher, A., Jaffry, S., Bennett, E. (2000). Normative and social influences affecting compliance with fishery regulations. Land Economics, 76(3), 448-461. 
Henrich, J. (2004). Cultural group selection, coevolutionary processes and large-scale cooperation. Journal of Economic Behavior and Organization, 53, 3-35.

Hermann, B., Thöni, C., Gächter, S. (2008). Antisocial punishment across societies. Science, 219 (5868), 1362-1367.

Hetherington, S.J. (2014). MB0125 \& C6122: common fisheries policy reform implementation: aligning zero quota species and improving fisheries management - a spurdog case study, Defra Funded Research Programme (2013-2015).

Holland, D.S., \& Jannot, J.E. (2012). Bycatch risk pools for the US West Coast Groundfish Fishery. Ecological Economics, 78, 132-147.

Imas, A., Sadoff, S., \& Samek, A. (2017). Do people anticipate loss aversion? Management Science, 63(5), 1271-1284.

Jacobsen, R.B., Wilson, D.C.K., Ramirez-Monsalve, P. (2012). Empowerment and regulation dilemmas in participatory fisheries science. Fish and Fisheries, 13, 291-302.

James, K.M., Campbell, N., Viðarsson, J.R., Vilas, C., Plet-Hansen, K.S., Borges, L., et al. (this volume). Tools and technologies for the monitoring, control and surveillance of unwanted catches. In S.S. Uhlmann, C. Ulrich, S.J. Kennelly (Eds.), The European Landing Obligation Reducing discards in complex, multi-species and multi-jurisdictional fisheries. Cham: Springer.

Jentoft, S. (1998). Social theory and fisheries co-management. Marine Policy, 22, 423-436.

Kahneman, D., \& Tversky, A. (1979). Prospect theory: an analysis of decision under risk. Econometrica, 47(2), 263-291.

Kelleher, K. (2005). Discards in the world's marine fisheries. An update. Rome: FAO. No. 470, 131 pp.

Kraak, S.B.M. (2011). Exploring the 'Public Goods Game' model to overcome the tragedy of the commons in fisheries management. Fish and Fisheries, 12(1), 18-33.

Kraak, S.B.M., Bailey, N., Cardinale, M., Darby, C., José, A.A.D.O, Eero, M., et al. (2013). Lessons for fisheries management from the EU cod recovery plan. Marine Policy, 37, 200-213.

Kraak, S.B.M., Kelly, C., Anderson, C., Dankel, D., Galizzi, M., Gibson, M., et al. (2015). ICES science fund 2014 project report: insights from behavioral economics to improve fisheries management. Report of the Workshop jointly funded by ICES and FSBI held 21-23 October 2014 at ICES HQ, Copenhagen, Denmark, 46 pp. http://www.ices.dk/community/ icessciencefund/Documents/06_Report\%20of\%20the\%20BehavFish\%20Workshop_final.pdf. Accessed 29 June 2018.

Kraak, S.B.M., Drupp, M.A., Quaas, M. (2016). Carrot or stick? Experimental tests on a potential trade-off between effectiveness and compliance of alternative management approaches, ICES CM 2016/B:293. http://www.ices.dk/sites/pub/ASCExtended2016/Shared\%20Documents/B\% 20-\%20Predictably\%20Irrational\%20\%E2\%80\%93\%20a\%20new\%20scientific\%20research\% 20 field $\% 20$ for $\% 20$ the $\% 20$ science $\% 20$ underpinning $\% 20$ marine-resource $\% 20$ management/ abstract\%20Kraak\%20Drupp\%20Quaas\%20-\%20carrot\%20stick\%20and\%20prosocial\% 20behaviour_final.pdf. Accessed 19 Nov 2018.

Kubanek, J., Snyder, L.H., Abrams, R.A. (2015). Reward and punishment act as distinct factors in guiding behaviour. Cognition, 139, 154-167.

Kuperan, K., \& Sutinen, J.G. (1998). Blue water crime: deterrence, legitimacy, and compliance in fisheries. Law \& Society Review, 32(2), 309-337.

Le Gallic, B., \& Cox, A. (2006). An economic analysis of illegal, unreported and unregulated (IUU) fishing: Key drivers and possible solutions. Marine Policy, 30, 689-695.

Mangi, S.C., Dolder, P.J., Catchpole, T.L., Rodmell, D., de Rozarieux, N. (2013). Approaches to fully documented fisheries: Practical issues and stakeholder perceptions. Fish and Fisheries, 16 (3), 426-452.

Mangi, S.C., Kupschus, S., Mackinson, S., Rodmell, D., Lee, A., Bourke, E., et al. (2018). Progress in designing and delivering effective fishing industry-science data collection in the UK. Fish and Fisheries. https://doi.org/10.1111/faf.12279. 
Mann, H., Garcia-Rada, X., Houser, D., Ariely, D. (2014). Everybody else is doing it: Exploring social transmission of lying behavior. PLOS ONE, 9(10), e109591. https://doi.org/10.1371/ journal.pone.0109591.

Mazar, N., Amir, O., Ariely, D. (2008). The dishonesty of honest people: A theory of self-concept maintenance. Journal of Marketing Research, 45(6), 633-644.

Mead, N.L., Baumeister, R.F., Gino, F., Schweitzer, M.E., Ariely, D. (2009). Too tired to tell the truth: Self-control resource depletion and dishonesty. Journal of Experimental Social Psychology, 45(3), 594-597.

Milinski, M., \& Rockenbach, B. (2007). Spying on others evolves. Science, 317(5837), 464.

Mortensen, L.O., Ulrich, C., Eliasen, S., Olesen, H.J. (2017). Reducing discards without reducing profit: Free gear choice in a Danish result-based management trial. ICES Journal of Marine Science, 74(5), 1469-1479.

Needle, C.L., Dinsdale, R., Buch, T.B., Catarino, R.M.D., Drewery, J., Butler, N. (2015). Scottish science applications of remote electronic monitoring. ICES Journal of Marine Science, 72(4), $1214-1229$.

Nielsen, J.R. (2003). An analytical framework for studying: Compliance and legitimacy in fisheries management. Marine Policy, 27(5), 425-432.

Nielsen, J.R., \& Mathiesen, C. (2003). Important factors influencing rule compliance in fisheries lessons from Denmark. Marine Policy, 27(5), 409-416.

Norton, M.I., Mochon, D., Ariely, D. (2012). The IKEA effect: When labor leads to love. Journal of Consumer Psychology, 22, 453-460.

O'Keefe, C.E., \& DeCelles, G.R. (2013). Forming a partnership to avoid bycatch. Fisheries, 38(10), 434-444.

Ostrom, E. (1990). Governing the commons: The evolution of institutions for collective action. New York: Cambridge University Press.

Ostrom, E. (1998). A behavioral approach to the rational choice theory of collective action: Presidential address, American Political Science Association, 1997 American Political Science Review, 92(1), 1-22.

Ostrom, E. (2001). Reformulating the commons. In J. Burger, E. Ostrom, R.B. Norgaard, D. Policansky and B.D. Golsdstein (Eds.), Protecting the commons. a framework for resource management in the Americas (pp. 17-41). Washington, DC: Island Press.

Ostrom, E. (2009). A general framework for analyzing sustainability of social-ecological systems. Science, 325, 419-422.

Ouwerkerk, J.W., Kerr, N.L., Gallucci, M., van Lange, P.A.M. (2005) Avoiding the social death penalty: Ostracism and cooperation in social dilemmas. In K.D. Williams, J.P. Forgas, W. von Hippel (Eds.), The social outcast: Ostracism, social exclusion, rejection and bullying. New York: Psychology Press.

Panagopoulos, C. (2010). Affect, social pressure and prosocial motivation: Field experimental evidence of the mobilizing effects of pride, shame and publicizing voting behavior. Political Behavior, 32, 369-386.

Prellezo, R., Kraak, S.B.M., Ulrich, C., et al. (2016). Research for PECH Committee - the discard ban and its impact on the maximum sustainable yield objective on fisheries: Workshop. Brussels: European Union.

Richter, A.P., \& van Soest, D.P. (2012). Global environmental problems, voluntary action and government intervention. In E. Brousseau, T. Dedeurwaerdere, P.-A. Jouvet, et al. (Eds.), Global environmental commons: Analytical and political challenges in building governance mechanisms (pp. 223-248). Oxford: Oxford University Press.

Schou, M. (2011). Introducing transferable fishing concessions - A check list for operative considerations, (15.08.2011), unpublished.

Schou, M. (2015). BalticSea2020, (16.06.2015), unpublished.

SeafoodSource (2018). First QR code sushi on UK menu. https://www.seafoodsource.com/news/ environment-sustainability/first-qr-code-sushi-on-uk-menu. Accessed 31 May 2018. 
Sumaila, U.R., Alder, J., Keith, G. (2006). Global scope and economics of illegal fishing. Marine Policy, 30, 696-703.

Thaler, R.H., \& Sunstein, C.R. (2009). Nudge, improving decisions about health, wealth and happiness. London: Penguin Books.

This Fish. (2018). http://thisfish.info. Accessed 31 May 2018.

Toonen, H.M., \& Bush, S.R. (2018). The digital frontiers of fisheries governance: Fish attraction devices, drones and satellites. Journal of Environmental Policy \& Planning. https://doi.org/10. 1080/1523908X.2018.1461084.

Tversky, A., \& Kahneman, D. (1974). Judgment under uncertainty: Heuristics and biases. Science, 185(4157), 1124-1131.

Tversky, A., \& Kahneman, D. (1991). Loss aversion in riskless choice: A reference-dependent model. The Quarterly Journal of Economics, 106(4), 1039-1061.

Tyler, T.R. (2006). Why people obey the law. Princeton: Princeton University Press.

van Helmond, A.T.M., Chen, C., Poos, J.J. (2015). How effective is electronic monitoring in mixed bottom-trawl fisheries? ICES Journal of Marine Science, 72, 1192-1200.

Vohs, K.D., Mead, N.L., Goode, M.R. (2006). The psychological consequences of money. Science, $314,1154-1156$.

Vyrastekova, J., \& van Soest, D. (2003). Centralized common-pool management and local community participation. Land Economics, 79(4), 500-514.

Wageningen University Research. (2018). Over Kenniskringen. https://www.wur.nl/nl/OnderzoekResultaten/Projecten/Kenniskring-Visserij/Over-Kenniskringen.htm. Accessed 31 May 2018.

Wilson, D.C., Nielsen, J.R., Degnbol, P. (Eds.). (2003). The fisheries co-management experience. Accomplishments, challenges and prospects. Dordrecht: Kluwer Academic Publishers.

Open Access This chapter is licensed under the terms of the Creative Commons Attribution 4.0 International License (http://creativecommons.org/licenses/by/4.0/), which permits use, sharing, adaptation, distribution and reproduction in any medium or format, as long as you give appropriate credit to the original author(s) and the source, provide a link to the Creative Commons license and indicate if changes were made.

The images or other third party material in this chapter are included in the chapter's Creative Commons license, unless indicated otherwise in a credit line to the material. If material is not included in the chapter's Creative Commons license and your intended use is not permitted by statutory regulation or exceeds the permitted use, you will need to obtain permission directly from the copyright holder. 